\title{
Basking shark breaching behaviour observations west of Shetland
}

\author{
Emma Hayes ${ }^{1 *}$, Brendan J. Godley ${ }^{2}$, Maja Nimak-Wood ${ }^{1}$ and Matthew J. Witt ${ }^{3}$
}

\begin{abstract}
This study reports observations of basking sharks (Cetorhinus maximus) sighted during an offshore geophysical survey conducted in July and August 2013, west of Shetland, UK. During the 38-day survey, trained and dedicated marine wildlife observers recorded 19 sightings of basking sharks ( $n=22$ individuals). Of these observations, 17 were of single sharks, with one observation of two sharks and one observation of three sharks. All surface sightings occurred in water depths between 129 and 199 m, predominantly prior to noon local time (79\%), and were mostly of sharks $6-8 \mathrm{~m}$ in length, although a young $(2 \mathrm{~m})$ individual was also recorded. Breaching behaviour was observed on 21 occasions, by individuals or in small groups. Breaching has been proposed as a male-male competitive behaviour during courtship displays and female basking sharks may breach to signal their readiness for mating. Aggregations of basking sharks at frontal systems are well documented and linked to the occurrence of prey patches; however, these oceanographic features may also be of importance to courtship. The high number of sightings of sharks recorded during a relatively short time frame in addition to breaching behaviour and presence of young individuals, suggest that this area west of Shetland may be an important habitat for the basking shark.
\end{abstract}

Keywords: Basking shark, Cetorhinus maximus, West of Shetland, Breaching, Courtship

\section{Background}

The basking shark (Cetorhinus maximus) is the largest fish in UK waters and the second largest fish globally, reaching $12 \mathrm{~m}$ in length and weighing up to $4 \mathrm{t}$ (Sims, 2008). Basking sharks have been shown to feed where water masses meet, such as at interfaces between bodies of water, including tidal and oceanic fronts, typically with strong thermal gradients (Sims, 2008; Priede \& Miller, 2009). At these fronts, plankton are typically found in higher concentrations (Sims \& Quayle, 1998). Basking sharks follow their prey horizontally and vertically, and are known to forage over large distances often observed singly, or in pairs, but can be also found in large groups (Wilson, 2004; Crowe et al., 2018). Sightings in the Northeast Atlantic are usually recorded between April and October, with the peak number of sightings between June and August (Witt et al., 2012).

The European continental shelf is a particularly important habitat for basking sharks and although they can

\footnotetext{
* Correspondence: emma.hayes@gardline.com

${ }^{1}$ Gardline Limited, Endeavour House, Admiralty Road, Great Yarmouth NR30 3NG, Norfolk, UK

Full list of author information is available at the end of the article
}

demonstrate acute site fidelity to coastal regions, movements can be widespread (Doherty et al., 2017a; Doherty et al., 2017b; Sims et al., 2003; Southall et al., 2006). In the northeast Atlantic area they are considered Endangered by the IUCN (Fowler, 2009). Basking sharks have been shown to travel long distances to locate aggregated zooplankton, that can occur at frontal systems that can form in continental shelf and shelf-edge habitats (Sims \& Quayle, 1998; Sims et al., 2006). In shallow inner-shelf regions of the Northeast Atlantic, near thermal fronts, sharks have been known to exhibit reverse diel vertical migration (DVM), where they are typically near the surface during daylight hours. This is most likely due to the reverse DVM of basking sharks prey, Calanus $s p$. in the area (Sims et al., 2005).

In the UK, high relative densities of surface sightings occur on the west coast of Scotland, around the Isle of Man and on the southwest coast of England (Witt et al., 2012; Speedie \& Johnson, 2008; Speedie et al., 2009). There are two established hotspot sites in Scotland, which are the islands of Hyskeir and Canna situated in the Sea of the Hebrides, and the island of Coll (Gunna Sound, between Coll and Tiree) in the Inner Hebrides

(c) The Author(s). 2018 Open Access This article is distributed under the terms of the Creative Commons Attribution 4.0 International License (http://creativecommons.org/licenses/by/4.0/), which permits unrestricted use, distribution, and 
(Doherty et al., 2017a; Speedie et al., 2009). The Hyskeir and Canna hotspot support high numbers of sharks involved in putative courtship behaviour and is a site where breaching activity has been recorded (Speedie et al., 2009). The functional role of breaching has however yet to be resolved, but might involve intra-species communication to find mates or deter competing conspecifics for breeding opportunities (Sims et al., 2000). The occurrence and distribution of basking sharks to the west of the Shetland Islands (Fig. 1a; $60.5^{\circ} \mathrm{N}, 2.1^{\circ} \mathrm{W}$ ), remains poorly understood with only few sightings documented in this region over the past 20 years (Witt et al., 2012). A paucity of data potentially reflects the remote nature of this island archipelago, but also that data from offshore regions is limited by reduced sightings effort and subsequent reporting to public recording programmes, such as those operated by the Marine Conservation Society (UK) and the Shark Trust (UK). This study reports upon the sighting of basking sharks breaching to the west of Shetland, observed during marine wildlife observations made during $2 \mathrm{D}$ seismic survey activity.

\section{Methods}

Marine wildlife observations were conducted by experienced Marine Mammal Observers (MMOs) on an $80 \mathrm{~m}$ long seismic source vessel from July 2nd to August 9th 2013 in an area to the west of Shetland during hours of daylight. The survey route followed linear transects of between $\sim 15$ and $\sim 25 \mathrm{~km}$ length travelling either in a south-east to north-west (and reciprocal) or south-west to north-east (and reciprocal) direction; approximate travel speed during line transects was 4 knots; and approximate distance between transects was $2.5 \mathrm{~km}$ (Fig. 1a). Observers stationed $11 \mathrm{~m}$ above water level surveyed 360 degrees of visible seascape first searching by the naked eye for visual cues followed by focused following using binoculars. Locations of basking shark
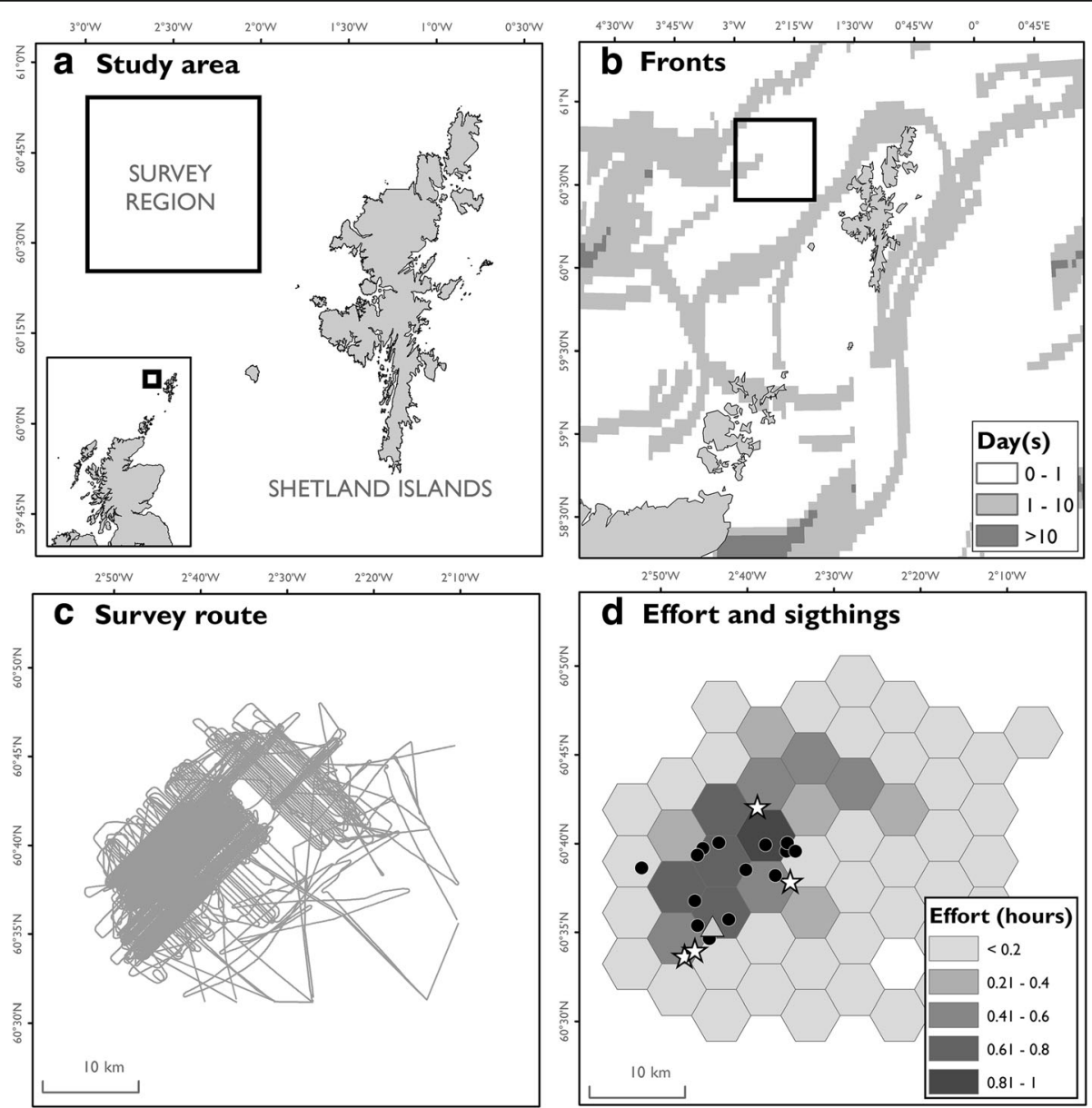

Fig. 1 Basking shark breaching behaviour recorded west of Shetland. a Shetland Islands, b presence of thermal fronts (shown as cumulative days front present within study period), c survey transects by seismic vessel and $\mathbf{d}$ cumulative survey effort (minutes) and sightings of breaching basking sharks (black filled circle), sharks observed slow swimming (white filled star) and surfacing (grey filled triangle) for the period July 2nd to August 9th 2013 
sightings were determined from the vessel location on first detection along with information on the bearing (degrees; 0 to 360 ) and distance $(\mathrm{m})$ to the sighting. Distance to sharks was estimated using a range finder (Heinemann 1981). Information on environmental conditions was recorded at either 60-min intervals or if weather or acoustic source activity changed. The observers recorded data on wind force (Beaufort scale; 0 to 12), sea state (glassy, slight, choppy, rough), visibility $<1 \mathrm{~km}$, $1-5 \mathrm{~km},>5 \mathrm{~km}$ ), sun glare (weak, strong, variable/forward, behind) and swell condition $(<2 \mathrm{~m}, 2-4 \mathrm{~m}$, > $4 \mathrm{~m}$ ). The instantaneous location of the survey vessel in decimal degree latitude and longitude (World Geodetic
System, 1984) was determined by an on-board GPS (at 1-s interval) and were archived to retrospectively calculate spatial-temporal search effort. Survey location data (GPS) were transformed to Universal Traverse Mercator Zone 30 prior to analysis. Survey effort was expressed as cumulative hours across the survey region using a grid (25 $\mathrm{km}^{2}$ cell area) to facilitate comparison with estimates of basking shark density (sharks $\mathrm{h}^{-1}$; SPUE) on the west coast of Scotland (Speedie et al. 2009). Seismic survey airguns operated continuously during the survey period ceasing occasionally during line turns and periods of adverse weather conditions. Acoustic impulses were made by a source array, which consisted of four air gun elements
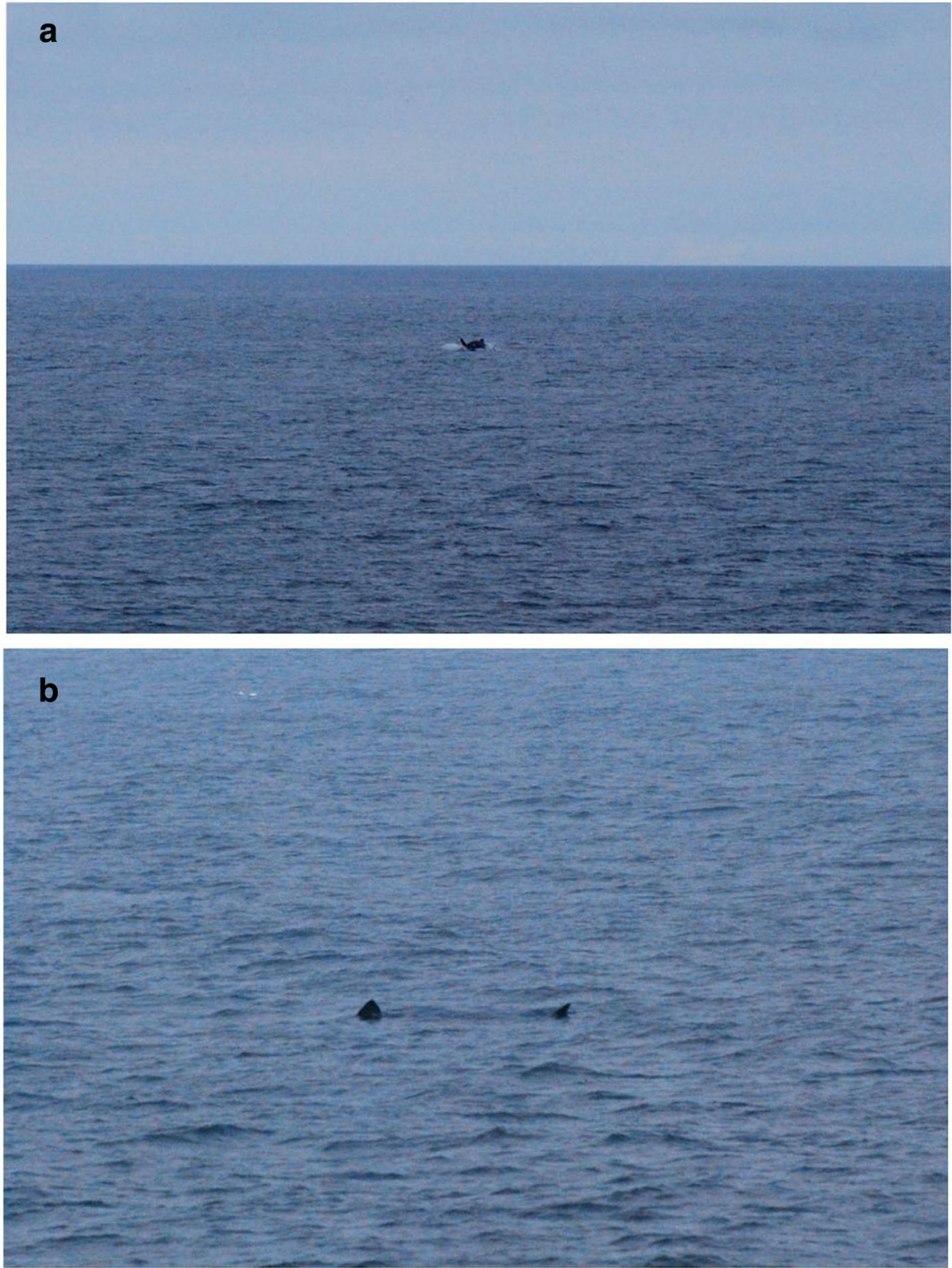

Fig. 2 Basking shark breaching (a) and surface behaviour (b) observed west of Shetland 
(total volume $160 \mathrm{in}^{3}{ }^{3}$ ). Cumulative presence of daily thermal fronts $\left(0.5^{\circ} \mathrm{C}\right.$ threshold) for the study period (38 days) were calculated from GHRSST L4 daily surface temperature data using the MGET Cayula-Cornillon fronts detection algorithm (Roberts et al., 2010).

\section{Results}

During the survey period (July 2nd to August 9th 2013; $n=39$ cumulative survey days), 19 sightings of basking sharks ( $n=22$ individuals) were recorded (Fig. 1). Weather conditions during this time were mostly favourable characterised with predominantly slight sea state (61\%), low swell (76\%), wind Beaufort force between 2 and 4 (79\%) and visibility exceeding $5 \mathrm{~km}(63 \%)$. Effort-corrected basking shark density ranged from 0 to 0.75 sharks (mean: 0.05) per cumulative hour of survey across the survey region. Distance from the survey vessel to sighted sharks on first detection ranged from $30 \mathrm{~m}$ to $3 \mathrm{~km}$ (median $800 \mathrm{~m}$, interquartile range $1450 \mathrm{~m}$ ). Sightings ranged from momentary observations up to $24 \mathrm{~min}$ in duration (median $1 \mathrm{~min}$., interquartile range $9 \mathrm{~min}$.). Of the observations, 17 were of single sharks, with one observation of two sharks and one observation of three sharks within close proximity of each other. The survey was conducted in linear transects thus reducing the probability of double counting basking sharks, which could result in overestimation. Basking sharks were observed breaching clear of the water on 21 occasions (Fig. 2a). All sightings were in water depths ranging from 129 to $199 \mathrm{~m}$. The majority of sightings $(79 \%)$ and breaching events (95\%) occurred prior to noon local time and were mostly of sharks approximately $6-8 \mathrm{~m}$ in length. Other observed behaviours were slow and directed swimming and surfacing (Figs. 1d and 2b). On one occasion an individual basking shark was sighted breaching three times in succession followed by another single breach approximately $20 \mathrm{~min}$ later. Two other basking sharks were sighted breaching twice on separate occasions, and a young basking shark $(\sim 2 \mathrm{~m}$ total length) was observed breaching after a nearby adult had breached.

\section{Discussion}

Breaching has been proposed as a male-male competitive behaviour during courtship displays and female basking sharks may breach to signal their readiness for mating (Sims et al., 2000). Basking sharks can aggregate in prey patches near fronts to feed, and as such this behaviour increases the likelihood of mature individuals meeting to initiate courtship (Sims et al., 2000). Frontal systems may therefore be oceanographic features of importance for feeding and for courtship. Should such breaching behaviour form part of courtship in the mating system of $C$. maximus then regions which support this behaviour may benefit from further research and enhanced wildlife management measures. Estimates of basking shark density for this survey are consistent with those from the west coast of Scotland, where Speedie et al. (2009) (Speedie \& Johnson, 2008) reported densities ranging from 0 to 4.46 sharks per cumulative hour of survey.

Although startle responses to acoustic sources have been recorded in some elasmobranch species, research in the behaviour of basking sharks and other elasmobranch species to seismic sources is poorly understood and yet to be investigated (Myrberg Jr et al., 1978; Carroll et al., 2016). This dataset is not of sufficient size to conduct a robust analysis and draw any conclusions on this issue.

\section{Conclusions}

Taking into consideration the number of sightings of basking sharks recorded during this survey, the breaching behaviour, the presence of young individuals as well as the suitability of the region in terms of oceanographic features, it is possible to suggest that this area west of Shetland may be an important habitat for basking sharks. Given the limited nature of this dataset, it is highly recommended that additional studies are conducted in the area to support these findings.

\section{Acknowledgements \\ We thank BP for permission to use data collected during the west of Shetland seismic survey campaign and for endorsing the publication of this work \\ Funding \\ The authors declare that no funding was received for this study.}

Availability of data and materials

All data made accessible during this study are included in this published article.

Authors' contributions

All authors contributed to data analysis and manuscript preparation. All authors read and approved the final manuscript.

Ethics approval and consent to participate

Permissions to conduct seismic surveying, from which this data resulted were acquired from relevant authorities by the data owners.

Consent for publication

Not applicable.

Competing interests

The authors declare that they have no competing interests.

\section{Publisher's Note}

Springer Nature remains neutral with regard to jurisdictional claims in published maps and institutional affiliations.

\section{Author details}

${ }^{1}$ Gardline Limited, Endeavour House, Admiralty Road, Great Yarmouth NR30 3NG, Norfolk, UK. ${ }^{2}$ Centre for Ecology and Conservation, University of Exeter, 
Penryn Campus, Penryn, Cornwall TR10 9FE, UK. ${ }^{3}$ Environment and Sustainability Institute, University of Exeter, Penryn Campus, Penryn, Cornwall TR10 9FE, UK.

Received: 13 March 2018 Accepted: 2 July 2018

Published online: 02 August 2018

\section{References}

Carroll AG, Przeslawski R, Duncan A, Gunning M, Bruce B. A critical review of the potential impacts of marine seismic surveys on fish and invertebrates. Mar Pollut Bull. 2016;114 (2016):9-24

Crowe LM, O'Brien O, Curtis TH, Leiter SM, Kenney RD, Duley P, Kraus SD. Characterization of large basking shark Cetorhinus maximus aggregations in the western North Atlantic Ocean. J Fish Biol. 2018;92:1371-84.

Doherty PD, Baxter JM, Gell FR, Godley BJ, Graham RT, Hall G, et al. Long-term satellite tracking reveals variable seasonal migration strategies of basking sharks in the north-East Atlantic. Sci Rep. 2017b;7:42837.

Doherty PD, Baxter JM, Godley BJ, Graham RT, Hall G, Hall J, et al. Testing the boundaries: seasonal residency and inter-annual site fidelity of basking sharks in a proposed marine protected area. Biol Conserv. 2017a;209:68-75.

Fowler SL. Cetorhinus maximus (Northeast Atlantic subpopulation). The IUCN Red List Threatened Species 2009. www.iucnredlist.org. Accessed 1 Jan 2018.

Heinemann D. A range finder for pelagic bird censusing. J Wildl Manag. 1981; 45(2):489-93.

Myrberg AA Jr, Gordon CR, Klimley AP. Rapid withdrawal from a sound source by open-ocean sharks. J Acoust Soc Am. 1978:64:1289-97.

Priede IG, Miller PI. A basking shark (Cetorhinus maximus) tracked by satellite together with simultaneous remote sensing II: new analysis reveals orientation to a thermal front. Fish Res. 2009;95:370-2.

Roberts JJ, Best BD, Dunn DC, Treml EA, Halpin PN. Marine geospatial ecology tools: an integrated framework for ecological geoprocessing with ArcGIS, Python, R, MATLAB, and C++. Environ Model Softw. 2010;25:1197-207.

Sims DW. Sieving a living: a review of the biology, ecology and conservation status of the plankton-feeding basking shark cetorhinus maximus. Adv Mar Biol. 2008:54:171-220.

Sims DW, Quayle VA. Selective foraging behaviour of basking sharks on zooplankton in a small-scale front. Nature. 1998;393:460-4.

Sims DW, Southall EJ, Richardson AJ, Reid PC, Metcalfe JD. Seasonal movements and behaviour of basking sharks from archival tagging: no evidence of winter hibernation. Mar Ecol Prog Ser. 2003;248:187-96.

Sims DW, Southall EJ, Tarling GA, Metcalfe JD. Habitat-specific normal and reverse diel vertical migration in the plankton-feeding basking shark. J Anim Ecol. 2005;74:755-61.

Sims DW, Southall EJ Quayle VA, Fox AM. Annual social behaviour of basking sharks associated with coastal front areas. Proc R Soc Lond. 2000;267:1897-904.

Sims DW, Witt MJ, Richardson AJ, Southall EJ, Metcalfe JD. Encounter success of free-ranging marine predator movements across a dynamic prey landscape. Proc R Soc B. 2006;273:1195-201.

Southall EJ, Sims DW, Witt MJ, Metcalfe JD. Seasonal space-use estimates of basking sharks in relation to protection and political-economic zones in the north-East Atlantic. Biol Conserv. 2006;132:33-9.

Speedie CD, Johnson LA. The basking shark (Cetorhinus maximus) in West Cornwall. Key sites, anthropogenic threats and their implications for conservation of the species. Natural England Research Report NERR 0018. 2008.

Speedie CD, Johnson LA, Witt MJ. Basking shark hotspots on the west coast of Scotland : key sites, threats and implications for conservation. Commissioned Report 339. 2009.

Wilson SG. Basking sharks (Cetorhinus maximus) schooling in the southern gulf of Maine. Fish Oceanogr. 2004;13(4):283-6.

Witt MJ, Hardy T, Johnson L, McClellan CM, Pikesley SK, Ranger S, et al. Basking sharks in the Northeast Atlantic: spatio-temporal trends from sightings in UK waters. Mar Ecol Prog Ser. 2012;459:121-34.

\section{Ready to submit your research? Choose BMC and benefit from:}

- fast, convenient online submission

- thorough peer review by experienced researchers in your field

- rapid publication on acceptance

- support for research data, including large and complex data types

- gold Open Access which fosters wider collaboration and increased citations

- maximum visibility for your research: over $100 \mathrm{M}$ website views per year

At BMC, research is always in progress.

Learn more biomedcentral.com/submissions 